\title{
NILAI PENDIDIKAN KARAKTER DALAM TARI INAI PADA UPACARA PERKAWINAN ADAT MELAYU
}

\author{
Meliarika Widyanti Putri \\ Pascasarjana, Universitas Negeri Yogyakarta \\ Email: meliarikawidyanti@gmail.com
}

\begin{abstract}
Abstrak
Penelitian ini bertujuan untuk mendeskripsikan nilai pendidikan karakter dalam tari Inai pada upacara perkawinan adat Melayu. Penelitian ini adalah penelitian jenis kualitatif. Objek material penelitian ini adalah tari Inai, sedangkan objek formalnya adalah nilai pendidikan karakter. Subjek penelitian ini adalah pelatih tari Inai di Sanggar Megad Syah Alam. Instrumen utama di dalam penelitian ini adalah peneliti sendiri. Dalam melaksanakan penjaringan data, peneliti dipandu oleh panduan observasi, panduan wawancara, dan panduan dokumentasi. Hasil penelitian menunjukkan bahwa nilai pendidikan karakter yang terdapat dalam tari Inai dapat dikelompokkan menjadi empat macam, yaitu (1) nilai pendidikan karakter hubungannya dengan Tuhan, (2) nilai pendidikan karakter hubungannya dengan diri sendiri, (3) nilai pendidikan karakter hubungannya dengan sesama dan (4) nilai pendidikan hubungannya dengan kebangsaan.
\end{abstract}

Kata Kunci: nilai pendidikan karakter, tari Inai, upacara perkawinan Adat Melayu

\section{CHARACTER EDUCATION VALUE IN INAI DANCE IN MALAY WEDDING CEREMONY}

\begin{abstract}
This research aims to describe the value of character education of Inai dance in Malay wedding ceremony. It is a qualitative research with Inai dance as an object of the research and value of character education plays as formal object. The subject of this research was the dance instructors in Sanggar Megad Syah Alam. The instrument was the researcher herself. The data was gathered through observation and interview guidelines, and documentation. The result shows that there were foru group of values of character education: (1) God value; (2) Self awarnes value; (3) caring other; (4) patriotic value.
\end{abstract}

Keywords: value of character education, Inai dance, Malay wedding ceremony

\section{PENDAHULUAN}

Pesatnya perkembangan teknologi informasi membawa dampak positif dan negatif bagi masyarakat terutama generasi muda. Kekhawatiran muncul dari dampak negatif yang lebih mudah merasuk dalam benak generasi muda dibandingkan dengan dampak positifnya. Media-media informasi baik cetak, elektronik maupun internet ikut berperan dalam merubah cara berpikir dan perilaku anak. Saat ini banyak tayangan-tayangan di televisi maupun media jejaring sosial yang menyuguhkan tindakan yang tidak bermoral dan jauh dari kaidah agama misalnya tayangan kekerasan, pornografi, dan pornoaksi. Tanpa disadari tayangan yang kurang layak tersebut ditirukan oleh generasi-generasi muda kita bahkan dijadikan sebagai panutan.

Semakinmaraknyatindakan penyimpangan sosial dan karakter yang dilakukan oleh para 
generasi penerus bangsa Indonesia membuat pemerintah tidak tinggal diam (Sutiyono, 2014: 49). Agar tidak semakin membudayanya tindakan tersebut dalamkalangan anak-anakdan remaja, maka pemerintah mulai menekankan pendidikan karakter disetiap lembaga pendidikan. Mengingat visi dari pembangunan nasional sendiri yaitu mewujudkan masyarakat yang berakhlak mulia, bermoral, beretika, berbudaya, dan beradab berdasarkan falsafah Pancasila. Melalui pendidikan karakter diharapkan dapat dijadikan pedoman untuk memperkuat karakter bangsa ke arah yang lebih baik, karena puncak peradaban dunia dapat tercapai hanya dengan bangsa yang berkarakter kuat. Keamanan, kesejahteraan, dan ketertiban akan terjadi jika karakter yang baik tertanam pada setiap individu.

Seni tari merupakan salah satu media yang dapat dipergunakan untuk menanamkan karakter kepada anak. Perkembangan motorik dan psikomotorik pada anak juga dapat terasah ketika menari. Nilai-nilai positif yang terkandung dalam gerak, iringan, maupun busana tari yang dikenakan dapat mengajarkan kepada anak untuk berfikir dan berperilaku positifdalamlingkunganmasyarakat. Seseorang yang berkarakter baik akan lebih dihargai dibandingkan dengan orang yang pintar namun tidak memiliki karakter yang baik. Mempelajari tari dengan sungguh-sungguh dan kedisiplinan yang tinggi dapat membuat seseorang belajar untuk mengendalikan dirinya dari hal-hal yang kurang baik.

TariInaimerupakansalahsatutaritradisional yang masih bertahan pada upacara perkawinan adat Melayu di Daik Lingga. Kemasan dari tari inai sangatlah sederhana, mengandung makna dan nilai-nilai yang tentu saja membentuk karakter masyarakat Melayu. Berdasarkan pengamatan semakin maraknya tindakan penyimpangan sosial dan penyimpangan karakter yang dilakukan oleh generasi muda serta pentingnya pendidikan karakter sejak dini untuk membentuk kepribadian yang baik pada anak, maka penting dilakukan penelitian tentang "Nilai Pendidikan Karakter dalam tari Inai pada Upacara Perkawinan Adat
Melayu". Penelitian ini diharapkan dapat digunakan untuk membantu pembentukan karakter yang baik pada anak. Selain itu, dapat mengimplementasikannya dalam kehidupan sehari-hari, sehingga dikemudian hari dapat menjadi warga masyarakat yang baik dan sadar akan tata kehidupan serta jauh dari sikap-sikap yang merusak.

\section{METODE}

Penelitian berjudul "Nilai Pendidikan Karakter Tari Inai pada Upacara Perkawinan Adat Melayu", ini menggunakan metode kualitatif. Penelitian kualitataif adalah penelitian yang bermaksud untuk memahami fenomena tentang apa yang dialami oleh subjek penelitian misalnya perilaku, persepsi, motivasi, tindakan, dan lain-lain secara holistik, dan dengan cara deskriptif dalam bentuk katakata dan bahasa, pada suatu konteks khusus yang alamiah dan dengan memanfaatkan berbagai metode alamiah (Moleong, 2012).

\section{HASIL DAN PEMBAHASAN \\ Sejarah Tari Inai}

Tari Inai merupakan tari tradisional masyarakat Melayu yang secara turun temurun dilakukan pada upacara adat perkawinan Melayu, yang diciptakan saat pemerintahan Kesultanan Lingga-Riau. Dalam hal ini biasanya tari tersebut dipersembahkan kepada pengantin yang duduk di atas pelaminan setelah akad nikah pada rangkaian prosesi tepuk tepung tawar.

Tari Inai sangat terkenal di Pulau Sumatera akan tetapi tarian ini jarang dipertunjukkan dibanding tari tradisional Melayu yang lain, dikarenakan tarian ini biasanya hanya ditampilkan pada acara-acara khusus seperti perkawinan, dan juga penabalan ataupun penobatan Raja yang ada pada zaman tersebut. Tari ini juga merupakan tarian yang sangat penting keberadaannya pada saat ada peristiwa penting zaman dahulu, karena tidak sembarang orang juga dapat melihat tarian ini.

Tari Inai adalah tari yang nyaris terdapat di seluruh daerah Melayu di Sumatera Utara seperti Langkat, Deli Serdang, Asahan, maupun 
Labuhan Batu. Masing-masing masyarakat Melayu di daerah tersebut membuat tari Inai sesuai dengan keadaan alam, ungkapan dan falsafah yang dimilikinya. Oleh karena itu, tari Inai bisa sangat beragam antara daerah Melayu yang satu dengan daerah Melayu lainnya juga memiliki persamaan dan perbedaan sendiri. Baik persamaan ragamnya, istilah geraknya, garis edar pola lantainya, sampai kepada properti yang digunakannya.

Meski demikian keberadaan tari Inai dimanapun tetap sama, yaitu sebagai bagian dari prosesi pemberian tanda yang dinamakan Inai kepada pengantin laki-laki dan perempuan. Tari Inai merupakan salah satu sarana upacara adat masyarakat Melayu di Kabupaten Lingga yang bisa dikatakan sebagai pelengkap upacara adat, yang dilakukan oleh golongan masyarakat yang tingkat perekonomiannya relatif baik. Tarian ini dipertunjukkan saat sub bagian upacara pernikahan yang disebut dengan malam berinai besar/ malam bertepuk tepung tawar. Tarian ini biasanya hanya dilakukan di rumah pengantin perempuan saja setelah melaksanakan akad nikah, sedangkan di rumah pengantin lali-laki tidak dilakukan. Hanya saja Inai dihantar dari rumah pengantin perempuan kerumah pengantin laki-laki kemudian dilanjutkan pemasangan Inai ke kuku jari-jari tangan dan kakinya oleh mak inang.

\section{Fungsi Tari Inai}

Pertunjukan Tari Inai bukanlah satusatunya pertunjukan dalam konteks upacara perkawinan adat Melayu. Pertunjukan ini hanya merupakan salah satu bagian saja dari berbagai seni pertunjukan dalam satu rangkaian upacara adat perkawinan Melayu secara lengkap. Ketika pengantin wanita dan pria telah duduk di pelaminan tari Inai di tarikan sebelum melaksanakan tepuk tepung tawar.

Menurut persepsi masyarakat Melayu, pada zaman dulu Inai diartikan sebagai penambah tenaga jasmani dan rohani yang memakainya serta menolak bala atau musibah, terutama bahaya yang ditimbulkan oleh makhluk-makhluk halus yang jahat. Sejalan dengan informasi yang dikemukakan oleh
Datok Muniziri, Tari Inai ditampilkan di depan pelaminan, gunanya untuk menghormati dan menghibur pengantin, memberikan perlindungan dan menambah kekuatan serta ketahanan fisik maupun batin. Dalam sistem kosmologinya, etnik Melayu pada umumnya percaya bahwa penyakit pertama kali datang dari ujung kaki dan tangan, maka pada bagian inilah Inai ditempelkan. Setelah masuknya Islam, kegunaan tari Inai untuk menjaga calon pengantin berangsur-angsur tidak lagi dipercayai. Setelah masuknya agama Islam dalam kehidupan etnik Melayu, dan dijadikan sebagai pandangan hidup berupa adat bersendikan syarak dan syarak bersendikan kitabullah, maka kegunaaan tari Inai adalah sebagai hiburan yang mengandung nilainilai estetis dan ekspresi ritual, serta sebagai penanda bahwa sepasang pengantin sudah sah menjadi suami dan isteri dan sebagai salah satu identitas budaya Melayu dalam aktivitas perkawinan.

Jika ditinjau dari konsep dasar Melayu yang berazaskan agama Islam, maka hal ini dapat diterima dan dipercayai oleh masyarakat Melayu sebagai aturan-aturan adat dan nilai keindahan setempat yang dilakukan secara simbolis serta mengandung makna tersendiri. Keterikatan antara adat Melayu dengan Islam tercermin dalam ungkapan "adat bersendikan syarak (hukum Islam), syarak bersendikan kitabullah (Alquran)". Salah satu fungsi adat dalam adat Melayu adalah untuk menjaga syariat Islam, yang berarti adatlah yang menjaga hukum (syariat). Dalam menjalankan kegiatan adat, suku Melayu tetap berlandaskan pada ajaran Islam, hal-hal yang mengenai peraturan adat disesuaikan dengan aturan-aturan dalam Islam. Selain itu, mereka juga taat dalam menjalankan kewajiban yang diajarkan dalam Islam.

\section{Bentuk Penyajian Tari Inai}

Bentuk penyajian adalah suatu cara menyampaikan pertunjukan yang disertai pendukung tarinya yang meliputi gerak tari, desain lantai, tata rias, dan busana, tempat pertunjukan dan iringan tari (Soedarsono, 1978:23). Pada pembahasan ini akan mengurai 
aspek pendukung tari Inai yang meliputi: 1) gerak tari, 2) pola lantai, 3) tata rias, 4) tata busana, 5) tempat petunjukan, dan 6) iringan tari yang mengiringi tari tersebut hingga menjadi sebuah sajian yang menarik untuk ditonton. Tetapi dalam penelitian ini hanya memfokuskan kepada ragam gerak tari Inai. Penjelasan bentuk penyajian tari Inai akan dijelaskan sebagai berikut.

\section{a. Gerak Tari}

Tari Inai yaitu bentuk tari tunggal yang ditarikan olehsatu orang penari. Tariinibiasanya bisa ditarikan oleh laki-laki maupun perempuan secara bergantian. Karakteristik tari tersebut adalah lembut dan menggunakan motif gerak yang berbeda dari tari Melayu biasanya. Motif yang biasa dilakukan oleh penari laki-laki yaitu menggunakan motif gerak Elang Mengimbang yang dimulai pada langkah tiga. Sedangkan motif gerak yang digunakan perempuan yaitu dimulai pada langkah dua motif Burung Kedidi. Tetapi pada dasarnya gerak yang digunakan laki-laki maupun perempuan hampir sama, yang membedakannya yaitu terdapat pada penyebutan nama dan volume gerak.

Muhammad Yusuf ( wawancara tanggal 28 Maret 2018 ), makna dalam ragam gerak tari Inai adalah sebagai berikut.

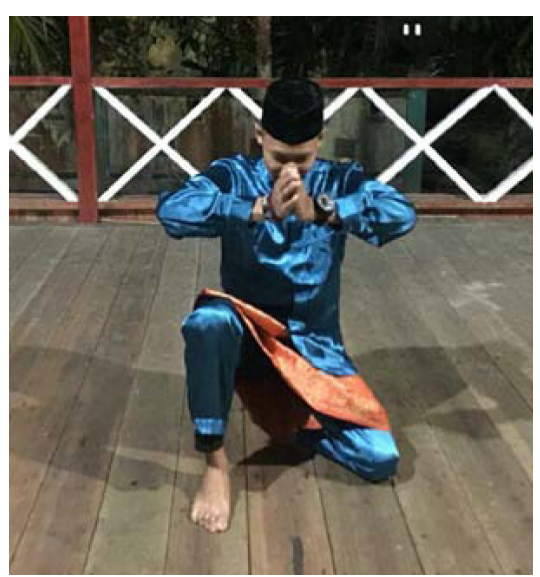

Gambar 1. Ragam gerak sembahan dalam Tari Inai.

Keterangan: posisi kaki kiri sebagai tumpuan di lantai, kaki kanan di tekuk, posisi kedua tangan melakukan sembah, kedua siku sedikit membuka. (Foto Meliarika)

\section{1) Sembahan}

Gerak tariawalan inibermaknapermohonan kepada yang Maha Kuasa agar dalam melaksanakan tugas atau kegiatan diberi pelindungan dan penghormatan kepada pengantin serta tamu yang berada didalam majelis perkawinan.

2) Bejalan Menarah

Didalam filosofi atau makna simbolis gerak Bejalan Menarah mempunyai makna yaitu pergi mencapai satu tujuan yang ingin dicapai. Bahwa tujuan dari segala sesuatu yang kita lakukan adalah mencari ridho sang pencipta.

3) Menebas

Gerak ini diartikan agar setiap manusia menghadapi segala rintangan kehidupan dengan berani. Tercermin dari gerak tarinya, tangan kanan mengibaratkan parang untuk menebas rumput menandakan untuk mencapai sebuah tujuan tidaklah mudah, dan harus berani menghadapinya.

4) Memilah

Memilah bermakna bahwa kita harus cerdas menentukan pilihan yang baik untuk masa depan kita.

5) Menggiling

Menggiling berarti menyatukan segala sesuatu hal yang baik untuk menjadi amalan kehidupan.

6) Menyecah

Menyecah diartikan bahwa seseorang mencoba mengambil sececah inai/ sedikit inai yang sudah diberi do'a sebagai penolak bala.

7) Melambai

Melambai diartikan sebagai penanda siap untuk membangun rumah tangga dan siap menghadapi rintangan kehidupan.

\section{b. Pola Lantai}

Pola Lantai adalah garis-garis lantai yang dilalui oleh seorang penari atau garis-garis di lantai yang dibentuk oleh formasi (Sumandyo Hadi, 2003: 12). Tari Inai adalah tarian solo dancer atau tarian yang ditarikan oleh satu orang penari. Karakteristik tari tersebut adalah tari lembut dan menggunakan motif gerak 
Elang Mengimbang dan Burung Kedidi. Pola lantai yang digunakan dalam tarian ini tidak banyak, karena tari ini hanya ditarikan oleh satu orang penari.

\section{c. Properti Tari}

Propertiyang digunakan dalamtari initerdiri dari 3 macam yaitu, (1) inai adalah tumbuhan yang hidup didataran tinggi yang memiliki daun yang lebat dan berukuran relatif kecil. Daun yang telah tua ditandai dengan adanya bintikbintik hitam yang terdapat di daun tersebut, daun yang tua itulah yang digiling halus dicampur dengan gambir dan kapur dan dibubuhkan pada kuku atau kulit sehingga menghasilkan warna kemerah-merahan. Pemakaian inai pada upacara perkawinan memiliki pengaruh dari arab, karena Inai dipercaya dapat menangkal roh jahat dan sebagai obat untuk luka dikulit, tetapi seiring berkembangnya pengetahuan masyarakat, sekarang Inai digunakan dalam masyarakat Melayu sebagai tanda sudah menikah. (2) Senjong sebagai tempat untuk meletakkan inai yang sudah digiling tersebut, sehingga memudahkan para penari untuk membawanya ke dalam tarian. (3) lilin gunanya untuk menerangi setiap senjong dan inai yang dibawa, serta memiliki makna dan simbol dalam tarian.

Selain digunakan sebagai pendukung sebuah tari, properti juga sering dipakai sebagai nama, judul dari sebuah tarian, misalnya properti payung untuk tari payung, properti piring untuk tari piring, keris untuk tari keris, dan lain-lainnya. Jadi, properti yang digunakan penari pada Tari Inai adalah 1 buah lilin, 1 buah Senjong dan Inai secukupnya, lilin di tegakkan di tengah-tengah tumpukan Inai pada Senjong.

Berikut adalah Senjong dan lilin sebagai properti tari Inai.

\section{d. Tata Busana}

Tari Inai menggunakan kostum Melayu pada umumnya yaitu Baju Kurung. Penari laki-laki menggunakan 1 stel baju kurung cekak munsang, kain samping/kain songket, aksesoris kepala untuk laki-laki yaitu hanya menggunakan songkok/peci. Sedangkan perempuan menggunakan 1 stel baju kurung kebaya labuh berleher tulang belut, berkacing seperti teluk belanga, kain samping/kain songket, subang, kemudian untuk aksesoris kepala, perempuan hanya menggunakan sanggul bulat dan ditutup dengan tudung manto/tudung lingkup/tudung kepala.

Berikut ini adalah foto keseluruhan kostum tari Inai.

\section{e. Tempat Pertunjukan}

Tempat pertujukan adalah tempat berlangsungnya sebuah pertunjukan diman interaksi antara penari ditampilkan di hadapan penonton. Sistem penataan tempat pertunjukan merupakan salah satu faktor untuk menarik perhatian para penonton. Tempat pertunjukan juga bemacam-macam bentuknya, contohnya panggung tradisional dan panggung modern. Bentuk tersebut sesuai dengan situasi atau jenis pertunjukan, misalnya yang berkembang, di lingkungan tembok istana, yang bersifat ritual, maupun yang diperjualkan. Bentuk tempat pertunjukan pada dasarnya dibagi menjadi 3 jenis yaitu :

1. Bentuk Arena

Teater terbuka atau arena adalah pentas yang meniadakan batas pemisah dengan penonton. Daerah pemain di tengah dan penonton berada disekelilingnya. Bentuk ini meruakan bentukyang paling sederhana. Ada berbagai macam bentuk teater arena diantaranya: teater arena bentul tapal kuda, teater arena bentuk $U$, teater arena bentuk lingkaran, teater arena bentuk setengah lingkaran dan teater arena bentuk $\mathrm{L}$.

2. Bentuk Campuran

Bentuk campuran adalah bentuk arena pentas yang memiliki bentuk pencampuran dan teater arena dan teater prosenium dengan menggabungkan dan meniadakan beberapa sifatnya. Penggabungan tersebut adalah kesederhanaan pentas arena dan jarak yang jauh pada arena dan bentuk yang tertutup.

3. Bentuk Prosenium

Proscenium adalah bentuk pementasan yang memisahkan antara pemain atau 
pentas dengan penonton atau auditorium. Konstruksi dasar proscenium berasal dari analisis kedudukan, terdiri dari tiga bagian yaitu: Stage Block, House Block, Front Block.

Panggung merupakan tempat memvisualisasikan pertunjukan, Tari Inai sebagai bagian dari keseluruhan acara malam berinai. Secara visual panggung pertunjukan Tari Inai adalah di depan pelaminan (kursi pengantin), sehingga dapat dilihat dari tiga sisi penonton, yaitu dari belakang, kiri, dan kanan panggung. Penari masuk diawali dari luar panggung yang berada di depan calon pengantin, kemudian diadakanlah tarian tersebut di tengah panggung dengan jarak diantara penonton dari belakang dan di depan pelaminan. Tari Inai dapat disimpulkan sebagai salah satu jenis tarian masyarakat Melayu yang sudah lama dikenal dan disajikan pada saat kegiatan upacara malam berinai sebagai kegiatan khas masyarakat Melayu.

Berikut adalah gambar panggung tempat pertunjuksn tari Inai.

\section{f. Iringan Tari}

Tata iringan merupakan pendukung tari lain yang memegang peran penting di dalam suatu karya tari. Fungsi iringan dalam tari di samping untuk memperkuat ekspresi gerak tari, juga didesain sebagai ilustrasi, pemberi suasana, dan membangkitkan imaji tertentu pada penontonnya. Untuk menggambarkan suasana sedih, dengan kekuatan gerak saja tidaklah cukup. Dengan buatan iringan yang bernuansa sedih, ekspresi penari akan lebih terasa. Di samping itu, dengan iringan kita bisa dengan mudah memahami adegan-adegan atau gerakan-gerakan yang diperagakan oleh penari.

Desain iringan dalam konteks tari adalah suatu komposisi musik yang didesain khusus untuk mengiringi, memperkuat ekspresi, memberi ilustrasi, dan membingkai suatu garapan tari. Musik iringan tari adalah salah satu bentuk musik khusus yang berbeda dengan kompisisi musik yang didesain untuk pertunjukan mandiri. Ciri khususnya adalah selalu melekat dengan tarian yang diiringinya. Iringan dalam tari Inai menggunakan beberapa alat musik seperti gendang panjang sebanya 2 buah, gong, dan serunai.

\section{Kandungan Nilai Pendidikan Karakter dalam Tari Inai pada Upacara Perkawinan Adat Melayu}

Berdasarkan pemaparan di atas nilai pendidikan karakter dalam tari Inai dapat dilihat pada beberapa unsur penyajiannya. Peneliti mendeskripsikan nilai pendidikan karakteryang terkandung dalam tari Inai sesuai dengan nilainilai pendidikan karakter yang dikemukakan oleh (Asmani, 2011) yaitu nilai pendidikan karakter hubungannya dengan Tuhan, nilai pendidikan karakter hubungannya dengan diri sendiri, nilai pendidikan karakter hubungannya dengan sesama, dan nilai pendidikan karakter hubungannya dengan kebangsaan.

\section{NilaiPendidikanKarakterHubungannya dengan Tuhan}

Manusia adalah makhluk ciptaan Tuhan yang paling sempurna, segala yang ada di dunia selalu berhubungan dengan Tuhan Yang Maha Esa. Tari Inai mengajarkan beberapa tuntunan moral yang merupakan pendidikan karakter. Nilai pendidikan karakter hubungannya dengan Tuhan bersifat religius maksudnya segala pikiran, perkataan, dan tindakan seseorang diupayakan selalu berdasarkan atas kepercayaaan kepada Tuhan dan ajaran agama. Nilai-nilai pendidikan karakter religius hubungannya dengan Tuhan dapat berupa percaya, taat, berdoa, dan bersyukur kepada Tuhan. Nilai pendidikan karakter yang berhubungan dengan Tuhan terdapat pada bagian penyajian ragam gerak tari dan busana. Berikut ini adalah nilai pendidikan karakter hubungannya dengan Tuhan pada tari Inai.

a. Nilai pendidikan karakter hubungannya dengan Tuhan yang terdapat dalam gerak.

Nilai pendidikan karakter yang bersifat religius terdapat dalam ragam gerak yaitu sebagai berikut ini:

1) Sembahan, merupakan gerak awal dari tari Inai yang mana posisi kaki kiri sebagai tumpuan di lantai, kaki 
kanan di tekuk, posisi kedua tangan melakukan sembah, kedua siku sedikit membuka. Sembah dilakukan ketiga arah, yaitu depan atas, samping kiri dan samping kanan. Gerakan kedua tangan ke atas menggambarkan seseorang yang sedang berdoa kepada Tuhan, sedangkan penghormatan ke samping kiri dan kanan merupakan penghormatan kepada pengantin serta para tetua dalam majelis perkawinan. Gerakan kedua tangan ke atas menggambarkan seseorang yang sedang berdoa kepada Tuhan merupakan pencipta dan pengatur alam semesta, Yang Maha Kuasa, dan sumber segala kehidupan. Oleh karena itu perlu mengajarkan kepada anak agar selalu berdoa dan percaya kepada Tuhan Yang Maha Esa. Hal ini dapat dilakukan dengan cara mengajarkan kepada anak agar selalu mengawali segala kegiatan dengan berdoa kepada Tuhan, mengajarkan agar dikala senang maupun susah selalu bersyukur kepada Tuhan, dan mengajarkan agar anak rajin beribadah ke gereja, masjid, pura, dan lain sebagainya. Jika sejak dini anak sudah ditanamkan kepercayaan kepada Tuhan maka kelak saat dewasa akan memiliki iman dan kepercayaan yang kuat sehingga mampu menghindari perbuatan negatif. Berikut gambar ragam gerak sembah dalam tari Inai.

2) Melambai, yaitu kedua tangan diangkat tidak melebihi kepala dan digerakkan kekiri dan kekanan. Gerakan ini bermakna bersyukur karena bisa menghadapi dan melalui berbagai rintangan kehidupan. Hal ini mengajarkan kepada seseorang agar selalu mensyukuri telah diberi keselamatan, kesehatan, kebahagiaan, rejeki oleh Allah SWT. Berikut gambar ragam gerak melambai dalam tari Inai. b. Nilai pendidikan karakter hubungannya dengan Tuhan yang terdapat dalam busana.

Keterikatan antara adat Melayu dengan Islam tercermin dalam ungkapan "adat bersendikan syarak (hukum Islam), busana yang dikenakan dalam adat Melayu juga sangat berkaitan dengan Islam. Busana tari Inai yang dikenakan oleh perempuan dan laki-laki dalam adat Melayu tidak boleh terbuka dan tidak boleh ketat. Hal ini dikarenakan untuk menjaga marwah seorang penari dan supaya mudah untuk mengerjakan sholat. Dalam hal ini adat Melayu yang masih berlandaskan Islam mengajarkan kepada generasi muda agar tetap menjaga diri dengan berpakaian yang tertutup sesuai dengan ajaran Islam dan tetap menjalankan ibadah ketika sedang melaksanakan tanggung jawab. Apabila kita berpegang teguh dengan agama, maka terjagalah kita dari keburukan.

\section{NilaiPendidikanKarakterHubungannya dengan Diri Sendiri}

Nilai pendidikan karakter hubungannya dengan diri sendiri merupakan tuntunan yang ditujukan untuk diri pribadi dalam membentuk pikiran, sikap, perilaku, dan tindakan yang positif (Sutiyono, 2013: 314). Dalam tari Inai nilai pendidikan karakter hubungannya dengan diri sendiri terdapat dalam ragam gerak dan busana.

a. Nilai pendidikan karakter hubungannya dengan diri sendiri yang terdapat beberapa gerak dalam tari Inai.

1) Bejalan Menarah, yaitu kedua tangan diayun atas dan kebawah posisi kaki duduk bertumpu. Didalam filosofi atau makna simbolis gerak Bejalan Menarah mempunyai makna yaitu gagah dan berani pergi mencapai satu tujuan yang ingin dicapai. Hal ini mengajarkan agar seorang individu memiliki rasa percaya diri serta tegas dalam mengambil keputusan. Menanamkan rasa percaya diri pada anak dapat dilakukan dengan cara menghargai anak, memberi kebebasan anak untuk mengambil keputusan sendiri serta memberikan 
dukungan jika anak ingin melakukan tindakan yang positif. Berikut gambar ragam gerak bejalan menarrah dalam tari Inai.

2) Memilah, yaitu kedua tangan bergerak seperti milih atau memetik daun ke arah depan dan kedua kaki duduk bertumpu. Bermakna bahwa kita harus cerdas menerima hal positif dan meninggalkan hal negatif. Hal ini mengajarkan kepada anak agar dapat membedakan kebaikan dan keburukan. Salah satu contoh cara mengajarkan kebaikan dan keburukan pada anak adalah apabila anak berbohong maka orang tua harus menasehati bahwa yang dilakukan tersebut salah, tidak baik, merugikan orang lain serta melarang untuk melakukannya kembali. Selain itu, orang tua juga harus memberikan pengertian bahwa berkata jujur merupakan hal baik yang harus dilakukan karena jika berkata jujur maka seseorang akan dipercaya oleh orang lain dan mempunyai banyak teman. Berikut gambar ragam gerak memilah dalam tari Inai.

3) Menggiling, yaitu kedua tangan menuju kedepan lalu menekuk kedalam seperti menggiling. Menggiling dibutuhkan ketelatenan serta keseriusan agar sesuatuyangdigilingmendapatkanhasil yang memuaskan. Hal ini mengajarkan agar setiap individu untuk serius dan telaten. Mengajarkan segala sesuatu keinginan tidak mudah didapatkan, semua keinginan memerlukan perlu proses, ketelatenan dan serius agar tercapai. Berikut gambar ragam gerak menggiling dalam tari Inai.

4) Menebas, yaitu tangan kanan seperti parang bergerak dari samping arah ke depan dan kedua kaki duduk bertumpu. Ibarat sedang menghadapi musuh dengan berani. Hal ini mengajarkan agar setiap individu berani menghadapi sesuatu. Menanamkan keberanian menghadapi sesuatu yang akan terjadi. Dan siap siaga dengan segala kemungkinan. Berikut ragam gerak menebas dalam tari Inai.

b. Nilai pendidikan karakter hubungannya dengan diri sendiri yang terdapat pada properti tari Inai.

Properti tari Inai adalah senjong, yang terbuat dari tembaga berbentuk seperti corak dasar bunga kundur. Dalam filosofi adat Melayu, bunga kundur memiliki makna menjauhkan dari sifat sombong dan takabur. Hal ini mengajarkan kepada anak untuk tidak sombong dan takabur dengan apa yang sudah dimiliki. Dan membiasakan diri untuk tetap rendah hati terhadap semua orang. Berikut gambar properti yang digunakan penari Inai.

\section{Nilai PendidikanKarakterHubungannya dengan Sesama}

Manusia adalah makhluk sosial yang selalu hidup berdampingan dan membutuhkan bantuan dari orang lain. Hubungan yang baik harus selalu terjalin agar tercipta kerukunan dan perdamaian. Nilai pendidikan karakter hubungannya dengan sesama dalam tari Inai tidak hanya terdapat dalam unsur tarian. Kebiasaan dalam adat Melayu pun nilai pendidikan karakter dapat ditanamkan, karena pada dasarnya adat Melayu mengutamakan rasa kekeluargaan (Noviyanti, 2017: 110). Rasa kekeluargaan dapat memupuk rasa kebersamaan, kerukunan dan, dan toleransi.

a. Nilai pendidikan karakter hubungannya dengan sesama terdapat pada tempat pertunjukan.

Tempat pertunjukan tari Inai yang disekelilingnya dihiasi dengan tabir yang berwarna merah, kuning, hijau mengandung makna tersendiri. Dalam adat Melayu merah merupakan tanda persaudaraan dan keberanian. Kuning merupakan lambang kesucian atau keagungan, sedangkan hijau lumut merupakan lambang kesuburan dan kemakmuran. Secara tidak langsung tempat pertunjukkan tari Inai yang dikelilingi tabir mengajarkan bahwa disanalah salah satu tempat untuk mempererat silahturahmi 
antar sesama, menjaga kerukunan keluarga, dan menyatukan dua keluarga menjadi satu. Berikut gambar tabir merah, kuning, hijau yang dipasang mengelilingi pelamin.

\section{NilaiPendidikanKarakterHubungannya dengan Kebangsaan}

Nilai pendidikan karakter hubungannya dengan kebangsaan terdapat pada keseluran dari tari Inai pada upacara perkawinan adat Melayu. Dengan mempertahankan adat sama halnya menjaga budaya bangsa. Adat istiadat bisa dikatakan perisai dari budaya, sebab dalam adat istiadat ada peraturan-peraturan yang mampu membatasi suatu individu atau kelompok menerima pengaruh dari lingkungannya. Hal ini mengajarkan generasi muda pentingnya mempertahankan adat istiadat kita, karena adat istiadat dan budaya kita merupakan cerminan diri kita dan bangsa kita, maka jikalau kita sebagai seorang yang mengakui diri sebagai orang yang memiliki adat, sudah sepatutnya kita menjadi cerminan yang indah bagi adat kita agar dipandang dan dinilai sebagai adat yang menarik, berperilaku baik dan berjiwa selayaknya manusia yang benar.

\section{KESIMPULAN}

Nilai pendidikan karakter hubungannya dengan Tuhan bersifat religius. Pada tari Inai nilai yang diajarkan yaitu selalu percaya, ingat, bersyukur kepada Tuhan Yang Maha Esa dengan cara berdoa dan menaati perintah dan menjauhi laranganNya. Nilai pendidikan karakter hubungannya dengan diri sendiri, mengajarkan agar setiap individu memiliki pikiran, sikap, perilaku, dan tindakan yang positif. Dalam hal ini nilai yang ditanamkan adalah keberanian, percaya diri, teguh pada pendirian, dapat membedakan baik dan buruk, serius, tegas, telaten, sopan. Nilai pendidikan karakter hubungannya dengan sesama pada tari Inai mengajarkan kebersaman, kerukunan, solidaritas, toleransi, dan saling menghormati. Manusia merupakan makhluk sosial yang selalu membutuhkan bantuan orang lain, sehingga dalam kehidupan harus menjaga hubungan yang baik satu sama lain. Nilai pendidikan karakter hubungannya dengan kebangsaan pada tari Inai mengajarkan agar setiap individu memiliki rasa mempertahankan identitas bangsa melalui budaya.

\section{DAFTAR PUSTAKA}

Asmani, J. M. 2011. Buku Panduan Internalisasi Pendidikan Karakter di Sekolah. Yogyakarta: Diva Press.

Dewantara, K. H. 2004. Ki Hajar Dewantara (Bagian Pertama: Pendidikan). Yogyakarta: Majelis Luhur Taman Siswa Endraswara.

Kementerian Pendidikan Nasional. 2011. Panduan Pelaksanaan Pendidikan Karakter. Jakarta: Badan Penelitian dan Pengembangan Pusat Kurikulum dan Perbukuan.

Kementerian Pendidikan Nasional. (2010). Pengembangan Pendidikan Budaya dan Karakter Bangsa, Pedoman Sekolah. Jakarta: Kementerian Pendidikan Nasional.

Kementerian Pendidikan Nasional. (2018). Penguatan Pendidikan Karakter pada Satuan Pendidikan. Jakarta: Kementerian Pendidikan Nasional.

Koesoema, D. 2007. Pendidikan Karakter (Strategi MendidikAnak di Zaman Global). Jakarta: PT Grasindo.

Malik. A. (2009). Telaah Budaya Corak dan Ragi Unggulan Kabupaten Lingga. Tanjungpinang.

Lickona, T. 2013. Educating for Character (Terjemahan). Bandung : Nusa Media.

Moleong, L. J. 2012. Metodologi Penelitian Kualitatif (Edisi Revisi). Bandung: PT Remaja Rosdakarya.

Noviyanti, Siti Risa., Sutiyono, S. 2017. Bentuk, Perubahan Fungsi, dan Nilai-nilai Edukatif pada Musik Tari Japin Tahlul di Amuntai. Imaji: Jurnal Seni dan Pendidikan Seni, 15(1), 97-112.

Sutiyono. 2013. Penerapan Pendidikan Budi Pekerti sebagai Pembentukan Karakter Siswa di Sekolah. Jurnal Pendidikan Karakter 3, 309-320.

Sutiyono. 2014. Developing Humanism Through the Teaching and Learning of 
Traditional Arts in Indonesia. Asian Journal of Management Sciences \& Education, $3(2), 49-56$.
Thalib, M. I. 2009. Tata Cara Adat Perkawinan Melayu Di Daik Lingga. Pekanbaru. Unri Press. 